\title{
Structure and Microstructure of Coronary Dentin in Non-Erupted Human Deciduous Incisor Teeth
}

\author{
Luciane R.R S. COSTA ${ }^{1}$ \\ Ii-Sei WATANABE ${ }^{2}$ \\ Márcia C. KRONKA ${ }^{2}$ \\ Marcelo C.P. SILVA ${ }^{2}$ \\ ${ }^{1}$ Department of Pedodontics, School of Dentistry, Federal University of Goiás, Goiânia, GO, Brazil \\ ${ }^{2}$ Department of Anatomy, Institute of Biomedical Sciences, University of São Paulo, São Paulo, SP, Brazil
}

\begin{abstract}
The dentin structure of non-erupted human deciduous mandibular and maxillary central and lateral incisor teeth was studied employing light and scanning electron microscopy. For light microscopy, nitric-acid-demineralized and ground sections were used. The sections were stained by hematoxylin-eosin, picrosirius and azo-carmim methods, and ground specimens were prepared using a carborundum disk mounted in a handpiece. For SEM study, teeth were frozen in liquid nitrogen and fractured at longitudinal and transversal directions. Structurally, demineralization and ground methods revealed tubules with primary and secondary curvatures, canaliculi, giant tubules, interglobular dentin, predentin, and intertubular dentin. Scanning electron microscopy showed three-dimensional aspects of dentinal tubules, canaliculi, peritubular dentin, intertubular dentin, and predentin. This study contributes to knowledge about dentin morphology showing characteristics of teeth not yet submitted to mastication stress.
\end{abstract}

Key Words: deciduous tooth, dentin, scanning electron microscopy, pediatric dentistry.

\section{INTRODUCTION}

In spite of related research, the adhesive technique for restoration of deciduous teeth remains surrounded by questions, including the possible influence of dentinal structure.

Nör et al. (1) reported that there is scarce knowledge about micromorphology and composition of deciduous teeth and Agematsu et al. (2) also affirmed that while anatomical differences between permanent and deciduous teeth have been extensively studied, histological characteristics of deciduous teeth remain to be evaluated. The dentin of deciduous teeth revealed a thicker deciduous peritubular area compared to permanent teeth (3) and the presence of giant tubules, which are uncommon in permanent teeth $(2,4,5)$. Deciduous dentin also had a smaller diameter and tubular density than permanent dentin and, consequently, less permeability (6-10). It is also reported that these aspects depend on the age of the tooth (11).

However, these data (6-9) were based on mor- phology of exfoliated deciduous teeth, i.e., old teeth that were submitted to external stimulus (attrition, demineralization and remineralization challenges, restoring technical procedures, etc.), which induce the deposit of secondary and tertiary dentin. In pediatric dentistry, the clinician usually treats young teeth that might have dentin with fewer morphological alterations. Therefore, it is necessary to observe the dentin structure in the initial period of the tooth in the oral cavity.

The objective of the present paper was to study the structure of the coronary dentin of non-erupted deciduous incisors using light and scanning electron microscopy.

\section{MATERIAL AND METHODS}

Twenty-three non-erupted human deciduous mandibular and maxillary central and lateral incisor teeth were used in this study. Specimens presented at least one-third developed root. Teeth were extracted from recently dead 5-10-month-old children who were 
autopsied at the "Hospital das Clinicas" (University of São Paulo). Death was caused by infection and none of the children had any syndrome. The experimental protocol was reviewed and approved by the legal representative of that service.

After extraction, the teeth were cleaned and fixed in modified Karnovsky's solution containing 2\% paraformaldehyde and $2.5 \%$ glutaraldehyde, in $0.1 \mathrm{M}$ $(\mathrm{pH} 7.4)$ at $4^{\circ} \mathrm{C}(11)$. After $24 \mathrm{~h}$, samples were stored in $0.1 \mathrm{M}$ sodium phosphate buffer $(\mathrm{pH} 7.4)$ at $4^{\circ} \mathrm{C}$.

Four teeth were demineralized in $10 \%$ nitric acid for approximately 30 days. Samples were washed in 5\% sodium sulfate for $12 \mathrm{~h}$, dehydrated in increasing series of alcohol, and embedded in paraffin. Longitudinal and transversal 7- $\mu \mathrm{m}$ thick sections were made with a microtome (Reichert-Jung, Cambridge Instruments $\mathrm{GmbH}$, Nussloch, Germany) and mounted on glass slides. The sections were stained with hematoxylin-eosin, picrosirius and azo-carmin, and examined with a light microscope (Carl Zeiss, Jena, Germany).

For histologic study of coronary dentin prepared by the ground method, four incisors were sectioned longitudinally in three portions using a carborundum disk associated to a handpiece. The slices were prepared with abrasive disks and wood sandpaper and polished with water sandpaper. Finally, they were washed and dried, and assembled on lamina for light microscope analysis (Carl Zeiss).

Fifteen teeth were used for evaluation of coronary dentin structure by means of scanning electron microscopy. Ten specimens were fractured in the buccal-lingual direction, while they were kept frozen in liquid nitrogen. The other five incisors were transversally freeze-cracked close to the pulp horn, following a guideline on the enamel made by a carborundum disk mounted in a handpiece. All of the samples were dehydrated in increasing series of alcohol, cleaned in an ultrasonic apparatus (Gerador GA 200, Thornton Inpec Eletrônica SA, São Paulo, SP, Brazil) for $10 \mathrm{~min}$, and dried in filter paper for $24 \mathrm{~h}$. The samples were mounted on metal stubs and covered with gold in a sputter coater apparatus (Balzers Union SCD-040, Liechtenstein). The specimens were examined in the scanning electron microscope at $15 \mathrm{kV}$ (Jeol JSM-6100, Tokyo, Japan).

\section{RESULTS}

Microscopic aspects of primary dentin in non- erupted human deciduous incisor teeth are shown in Figures 1 to 6 , obtained by ground, demineralization and scanning microscopy methods.

The ground lamina (Figure 1) showed dentinal tubules in a longitudinal direction containing dead tracts. In proximity of the enamel-dentin junction, primary curvature of tubules presenting a convexity turned to the incisal region was noted. There was also tubule branching, known as dentinal canaliculi or enamel spindles, where they reach the enamel. Details of secondary curvatures are seen in figure 2 .

The incisal area above the pulp horn and related to dentinal tubules did not have primary curvatures, but presented a nearly but not quite straight course according to Figure 1. In that same area, interglobular dentin was observed.

As seen in the demineralizated tooth (Figure 3), there were holes of dentinal tubules, that were regular in diameter and distribution and were surrounded by intertubular dentin. Giant tubules and interglobular dentin were also present.

In SEM images (Figures 4 to 6), the dentinal tubules were revealed in external, middle, and internal layers of dentin. In some regions, intertubular dentin had an irregular and granular appearance. The peritubular dentin with compact and regular morphology delimited holes of dentinal tubules. This was also evident in internal layers but totally absent in predentin.

At the internal dentin (Figures 2 and 6) there were predentin structures whose tubules were probably larger in diameter than those noted at the internal area near the pulp dentin. Additionally, a collagen fiber network was observed inside the tubules in the predentin.

\section{DISCUSSION}

In this study, dentinal aspects were obtained exclusively from non-erupted deciduous incisor teeth at the beginning of root formation. In order to observe the original dentin, the specimens selected had not suffered injury related to tooth function in the oral cavity. Thus, our data confirm the true organization of dentin structures in comparison to the erupted deciduous and permanent teeth. Our exclusion criteria also comprised syndromic children, although in Down syndrome, for example, Bell et al. (13) did not report any alteration in dentin deposit or structure in deciduous teeth. 


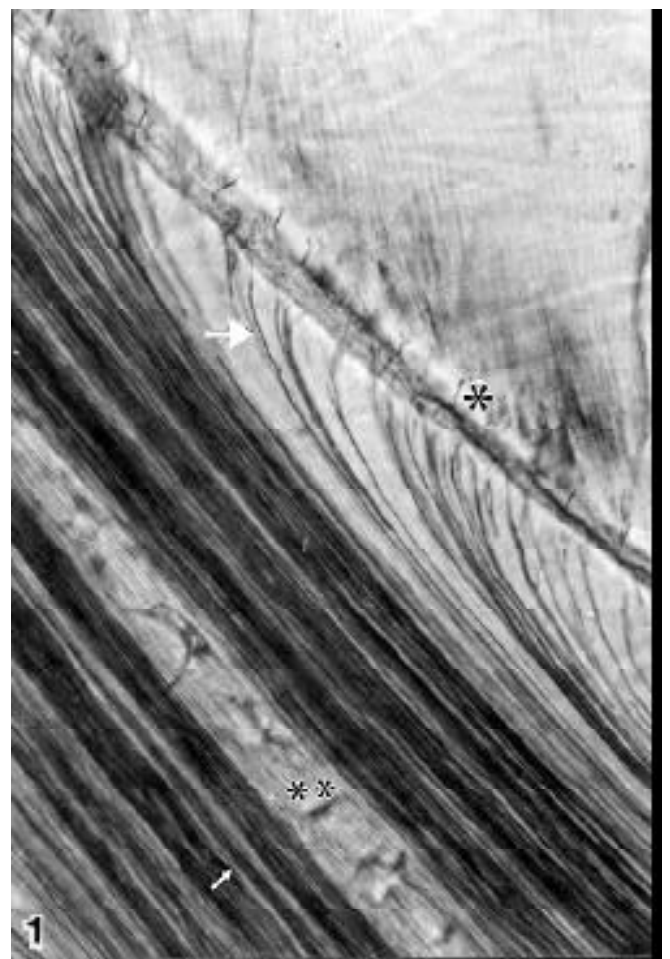

Figure 1. Longitudinal ground section of a non-erupted human deciduous incisor tooth showing enamel spindles (*), dentinal tubules with primary curvatures at enamel-dentin junction (large arrow), interglobular dentin (**), and dead tracts (small arrow). Original magnification: 100X.

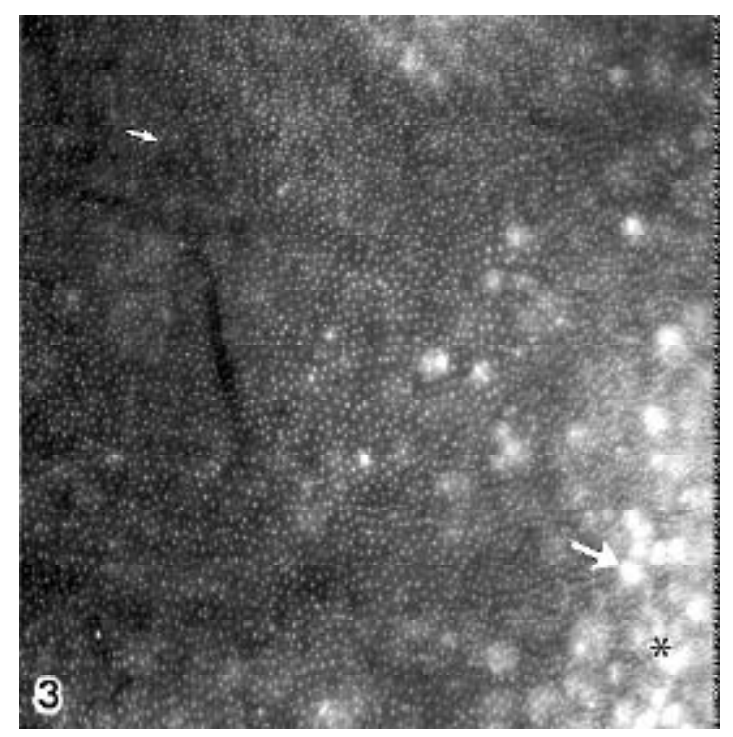

Figure 3. Transverse demineralized section of a non-erupted human deciduous incisor tooth showing dentinal tubule holes (small arrow), giant tubules (large arrow), and interglobular dentin (*). Picrosirius. Original magnification: 250X.

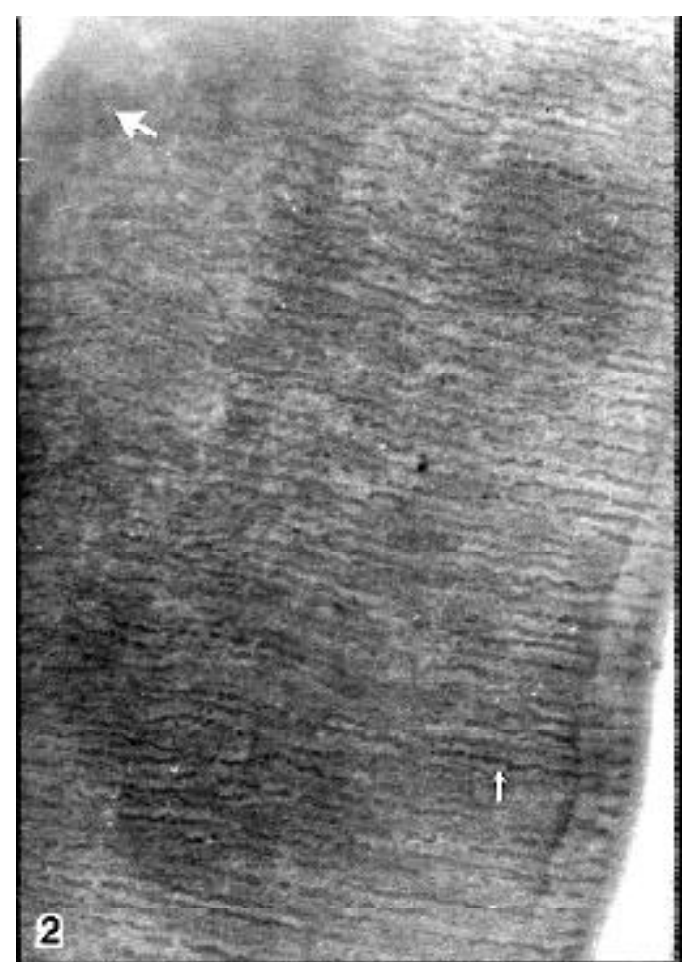

Figure 2. Longitudinal demineralized section of a non-erupted human deciduous incisor tooth showing secondary curvatures of dentinal tubules (small arrow) and predentin (larger arrow). Azocarmim. Original magnification: 250X.

Our results corresponded to studies in dentinal tubules by Mjör (11) and Kaqueler et al. (14), revealing that the tubules extended in the whole dentin, and also presented discrete primary curvatures mainly in the direction of buccal and lingual regions excluding the incisal area. These curvatures presented convexity or turned to incisal area, if they were observed closest to the amelo-dentinal junction, or to the root, when they were near the pulp chamber. Our results also showed secondary curvatures of dentinal tubules at regular intervals.

There was compact and regular peritubular dentin in three-dimensional SEM images, that was absent in predentin, as reported by Torneck (15). Its thickness was not measured, so we could not compare our results to those of Hirayama et al. (3), who reported values from 3 to 20 micrometers of thickness of peritubular dentin in deciduous teeth.

We observed that the intertubular dentin was irregular and granular. However, Bancev (16) identi- 


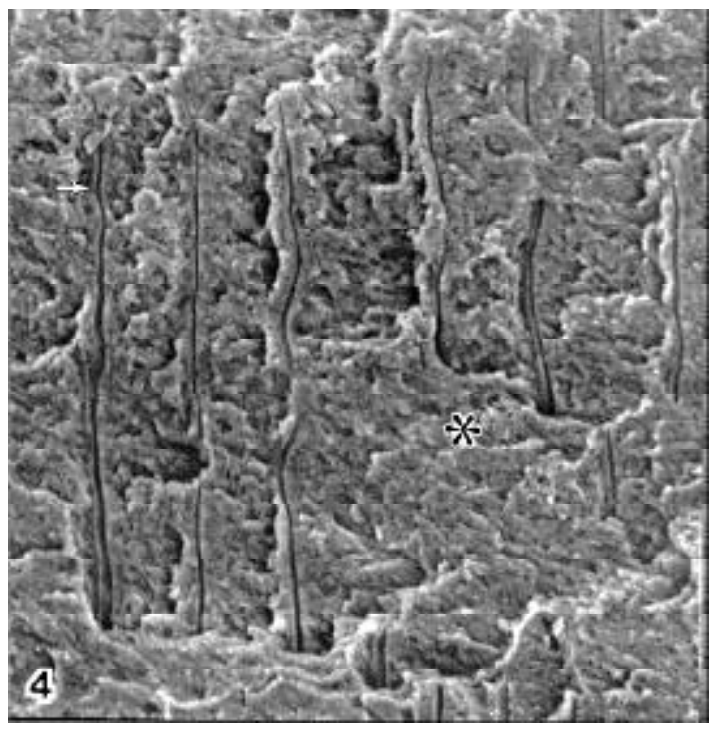

Figure 4. SEM image of a longitudinal fractured deciduous incisor. External dentin layer showing tubules (arrow) and intertubular dentin $(*)$. Original magnification: $2400 \mathrm{X}$.

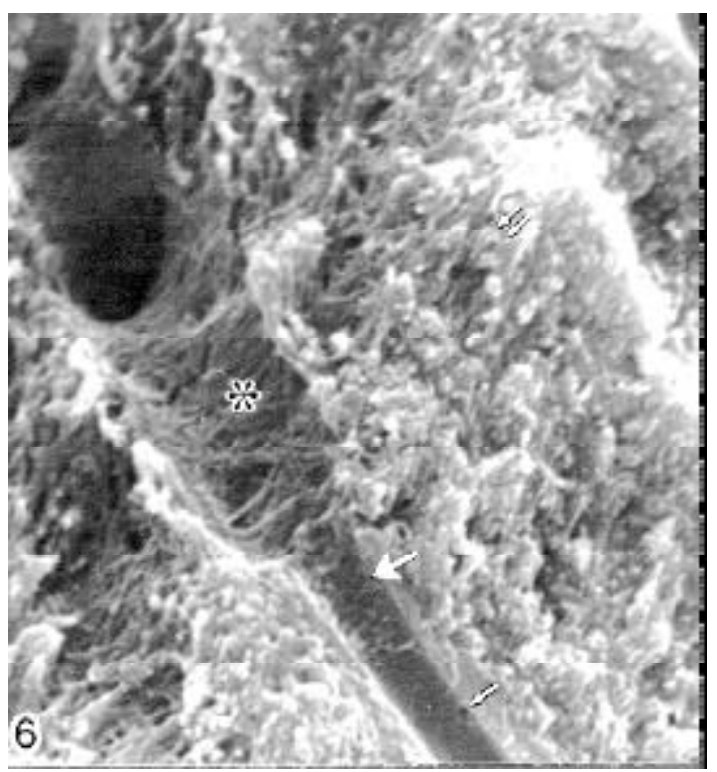

Figure 6. SEM image of a longitudinal fractured deciduous incisor. Predentin area showing dentin tubules (large arrow), peritubular dentin (small arrow), intertubular dentin (double arrow) and collagen fibers on tubule wall (*). Original magnification: $15000 \mathrm{X}$.

fied a net of collagen fibers in the intertubular area of deciduous teeth germs. This difference is probably due to methodological differences of the studies.

Near the enamel-dentin junction, there were also

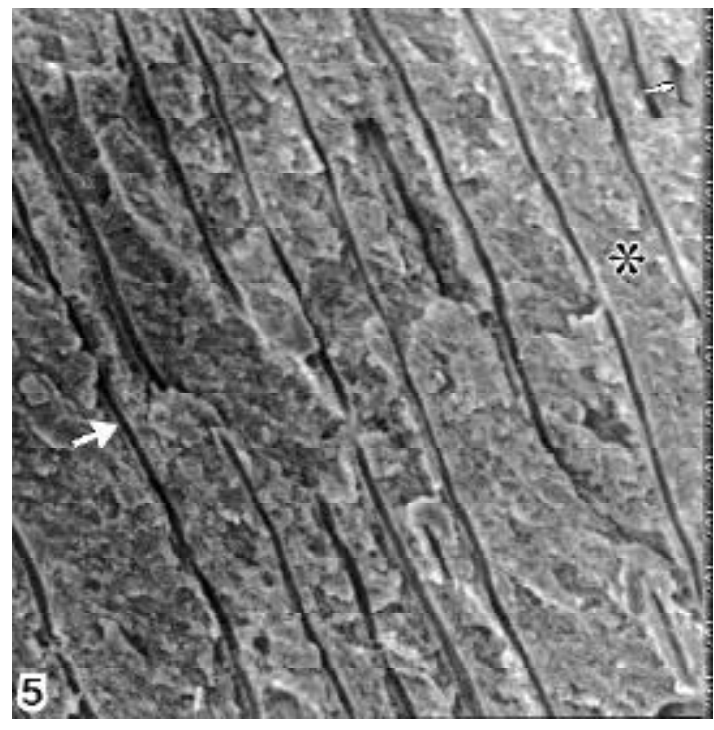

Figure 5. SEM image of a longitudinal fractured deciduous incisor. Middle dentin layer showing tubules (large arrow), intertubular dentin $(*)$, and dentin canaliculi (small arrow). Original magnification: $2400 \mathrm{X}$.

dentinal canaliculi, representing tubular ramifications of small caliber reaching the deepest layers of enamel in some cases. On the other hand, Kaqueler et al. (14) and Mjör and Nordahl (17) verified its predominance in the enamel-dentin junction.

In agreement with other authors $(2,4,5)$, we found microcanals or giant tubules in transverse sections of demineralized tooth. Sumikawa et al. (18) also observed giant tubules in deciduous central and lateral incisors, but not in canines, and they affirmed that giant tubules might have an important role in tooth sensitivity, carious lesion development rate and pulp pathology in cases of exposure during a dental trauma.

On the other hand, we identified a layer of interglobular dentin in the incisal area, above the pulp horn, as reported by Hals (5) and Agematsu et al. (2). They established a probable hypothesis for the occurrence of that structural entity associated to the giant tubules: there would be a collision of dentin formed in buccal and lingual surfaces, causing a disruption in dentinogenesis at the central area of incisal dentin. This could also happen due to inclusion of odontoblasts irregularly differentiated in that region.

Our observations showed a narrow and homogeneous layer of predentin, bounding the internal dentin, whose tubules had an inner dense network of collagen fibers. This morphological finding confirmed the 
smaller mineralization of predentin already described $(11,14,15)$.

The specimens prepared by the ground method demonstrated dead tracts inside the dentinal tubules. Torneck (15) attributed its presence to the intratubular space originally empty, but filled by air due to histological techniques. Hirayama et al. (3) also identified dead tracts in deciduous teeth, especially in the incisal margin of the dentin area.

Thus, we hope to have contributed not only to studies of dentin morphology, but also to clinical research. Other studies should be performed, using high resolution scanning electron microscopy techniques, to elucidate other aspects necessary for a better interpretation of these data.

\section{ACKNOWLEDGEMENTS}

The authors would like to thank to Wilson Roberto Campos de Azevedo, Marta Maria da Silva Righetti and Sebastião Aparecido Boleta for skilled technical assistance.

\section{RESUMO}

Costa LRRS, Watanabe I-s, Kronka MC, Silva MCP. Estrutura e ultra-estrutura da dentina coronária de incisivos decíduos humanos não erupccionados. Braz Dent J 2002;13(3):170-174.

A estrutura de dentina de dentes incisivos decíduos central e lateral não erupcionados humanos de mandíbula e maxila foi estudada empregando os métodos de microscopia de luz e eletrônica de varredura. Para a microscopia de luz foram utilizadas a solução de ácido nítrico para a desmineralização e cortes espessos por desgaste. Os cortes foram corados pelos métodos de hematoxilina-eosina, picrosirius e azo-carmin e os cortes espessos foram preparados utilizando-se de disco de carborundum montado em caneta de mão. Para a microscopia eletrônica de varredura, os dentes foram fraturados transversal e longitudinalmente mediante a congelação em nitrogênio líquido. Os métodos de desmineralização e de desgaste em cortes espessos revelaram estruturalmente, túbulos dentinários com curvaturas priomarias e secundárias, canalículos, túbulos gigantes, dentina interglobular, predentina e dentina intertubular. A microscopia eletrônica de varredura mostrou os aspectos tridimensionais dos túbulos dentinários, canalículos, dentina peritubular, dentina intertubular, e predentina. Este estudo contribui para o conhecimento sobre a morfologia dentinária mostrando características de dentes não submetidos às forças mastigatórias.
Unitermos: dente decíduo, dentina, microscopia eletrônica de varredura, dentística pediátrica.

\section{REFERENCES}

1. Nör JE, Feigal RJ, Dennison JB, Edwards CA. Dentin bonding: SEM comparison of the resin-dentin interface in primary and permanent teeth. J Dent Res 1996;75:1396-1403.

2. Agematsu H, Watanabe H, Yamamoto H, Fukayama M, Kanazawa T, Miake K. Scanning electron microscopic observations of microcanals and continuous zones of interglobular dentin in human deciduous incisal dentin. Bull Tokyo Dent Coll 1990;31:163-173.

3. Hirayama A, Yamada M, Miake K. An electron microscopic study on dentinal tubules of human deciduous teeth. J Tokyo Dent Coll Soc 1986;86:1021-1031.

4. Miller J. Large tubules in dentin. ASDC J Dent Child 1981;48:269-271.

5. Hals E. Observations on giant tubules in human coronal dentin by light microscopy and microradiography. Scand J Dent Res 1983;91:1-7.

6. Ketterl VW. Morphologische Untersuchungen über das Dentin der Milchzähne. Dtsch Zahnärtz Z 1965;20:652-657.

7. Fromme VHG, Riedel H. Messungen über die Weite der Dentinkanälchen an nichtentmineralisierten bleibenden Zähnen und Milchzähnen. Dtsch Zahnarztl Z 1970;25:401-405.

8. Watanabe I. Scanning electron microscopy of the pulp chamber walls in human deciduous upper incisor. Rev Odontol Univ São Paulo 1988;2:51-55.

9. Koutsi V, Noonan RG, Horner JA, Simpson MD, Matthews WG, Pashley DH. The effect of dentin depth on the permeability and ultrastructure of primary molars. Pediatr Dent 1994;16:29-35.

10. Costa LRRS, Watanabe I, Kronka MC. Coronal dentinal tubules of non-erupted deciduous incisors. Pesqui Odontol Bras 2002;16:12-17.

11. Mjör IA. Dentin and pulp. In: Mjör IA, Fejerskov O: Human embriology and histology. Copenhagen: Munksgaard; 1986. 90$130 \mathrm{p}$.

12. Karnovsky MJ. A formaldehyde-glutaraldehyde fixative of high osmolality for use in electron microscopy. J Cell Biol 1965;27:137A-138A.

13. Bell E, Townsend G, Wilson D, Kieser J, Hughes T. Effect of Down syndrome on the dimensions of dental crowns and tissues. Am J Human Biol 2001;13:690-698.

14. Kaqueler JC, Décombas M, Le May O. Le complexe odontoblastodentinaire. In: Structures bucco-dentaires en microscopie électronique a balayage. Paris: Masson; 1989. p 39-76.

15. Torneck CD. Dentin-pulp complex. In: Oral histology: development, structure and function. Ten Cate AR. ed. 3rd ed. St. Louis: Mosby; 1994. p 169-217.

16. Bancev M. Dentin ultrastructure of the temporary teeth Stomatologiia (Sofiia) 1973;55:270-275.

17. Mjör IA, Nordahl I. The density and branching of dentinal tubules in human teeth. Arch Oral Biol 1996;41:401-412.

18. Sumikawa DA, Marshall GW, Gee L, Marshall SJ. Microstructure of primary tooth dentin. Pediatr Dent 1999;21:439-444. 